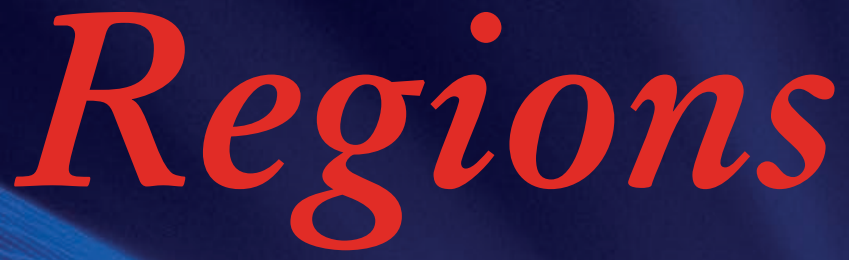

THEVOICE OF THE MEMBERSHIP NO 302,2016 ISSUE 2
QUARTERLY

MAGAZINE OF THE

\begin{tabular}{|c|}
\hline Regional \\
\hline Studies \\
\hline Association \\
\hline $\begin{array}{c}\text { THE GLOBAL FORUM FOR CITY } \\
\text { AND REGIONAL RESEARCH, } \\
\text { DEVELOPMENT AND POLICY }\end{array}$ \\
\hline
\end{tabular}

Issn: |367-3882

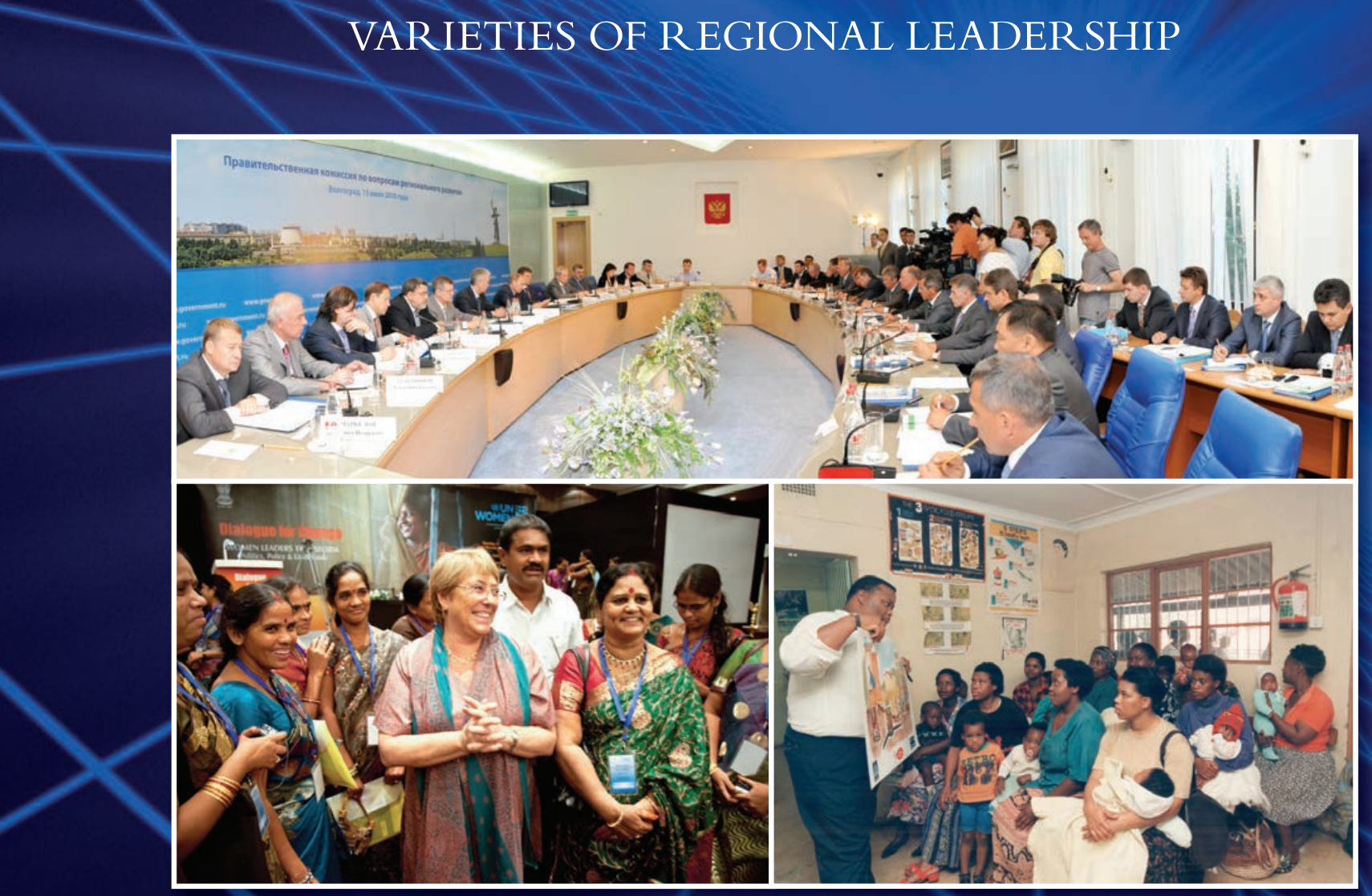

- EU Referendum in the UK: Regional Perspectives

- The growth paradigm and smart specialization in peripheral regions?

- Bergamot farm resilience in Italy 


\section{DEVELOPING A LEADERSHIP ADVANTAGE? AN ASSESSMENT OF THE IMPACT OF MAYORAL GOVERNANCE IN BRISTOL}

\section{Robin Hambleton, University of the West of England, Bristol, UK and David Sweeting, University of Bristol, UK}
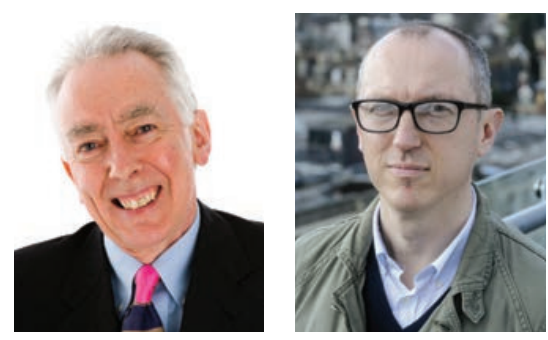

\section{Introduction}

In debates about how to improve the leadership of local governance, the idea of introducing executive mayors, directly elected by popular vote, has gained many adherents. The number of countries and cities that have decided to introduce the directly elected mayor form of governance has increased markedly in the period since the 1980's. For example, the following European countries have introduced directly elected mayors into their systems of local government (with dates): Slovakia (1990), Italy (1993), Germany (all Lander that did not already have directly elected mayors opted for them in the 1990's), Hungary (some cities in 1994, then all municipalities in 1998), Poland (2002) and the UK (in London in 2000 and in some other cities and localities in more recent years).

Reformers favouring this model of local governance argue, inter alia, that directly elected mayors can provide visible, strong and accountable leadership - in short, they can provide a locality with a leadership advantage. However, despite the unmistakable trend towards mayoral governance in a growing number of countries and notwithstanding the bold assertions made about the strengths of this leadership model, evaluation studies examining whether or not the claimed benefits actually materialise are thin on the ground. In this short article, we report on an action-research project being carried out in Bristol, UK in an attempt to start filling this leadership research gap.

Governance change in Bristol The Localism Act 2011 required the largest English cities outside London to hold referendums in May 2012 on whether or not to adopt a mayoral form of governance (Fenwick and Elcock, 2014). Ten referendums were held and nine cities, including Birmingham, Leeds, Manchester and Newcastle, rejected the idea. Bristol bucked the national trend. Here the citizens voted in favour of the introduction of a mayoral form of governance by a margin of around 5,100 votes. Following a lively contest between fifteen candidates, George Ferguson, an Independent politician (meaning he is not attached to any political party), was elected as Mayor of Bristol on 15 November 2012.

The Bristol Civic Leadership Project, which started in the summer of 2012, is a 'before' and 'after' study of the impact of the mayoral form of governance on the city. It centres on two important questions: 1) What difference does a directly elected mayor make? and 2) What steps can be taken to ensure that the introduction of a directly elected mayor brings about benefits and avoids potential disadvantages?

An active collaboration between the Universities of Bristol and the West of England, the research has involved surveys of citizens and civic leaders in 2012, before the mayoral model was introduced, and again in 2014, after the election of the city's first directly elected mayor. In addition, the researchers have run various workshops and focus groups with actors from inside and outside local government, both in Bristol and nationally, and have carried out face-to-face interviews with various key actors.

\section{Research findings}

A research report, The Impacts of Mayoral Governance in Bristol, which was presented to civic leaders in September 2015, provides a detailed analysis of the perceptions of different sets of actors and of different socio-economic groups within the city (Hambleton and Sweeting, 2015). Here we highlight some of the key findings.

The research has revealed valuable insights into attitudes towards the system of urban governance in Bristol that existed before November 2012, and into the way the mayoral model has performed in the period since it was adopted. It has also generated numerous ideas on how to improve the performance of the mayoral model of governance.

The research shows that the former system of governance, involving a council leader and cabinet, was regarded by many as being flawed in terms of visibility of the leader and effectiveness in decision-making.

The introduction of the mayoral model has resulted in a dramatic increase in the visibility of city leadership. In 2012, 24\% of citizens thought that the city had visible, leadership, whereas in 2014 this figure leapt to $69 \%$. Civic leaders from the community, voluntary and business sectors are even more positive about this change. Some 25\% thought that the city had visible leadership in 2012, a figure that soared to $97 \%$ in 2014.

Mayoral leadership has also led to a more broadly recognised vision for the city. Moreover, after the introduction of mayoral governance, $54 \%$ of citizens agreed that a directly elected mayor had improved the leadership of the city.

On the downside, our research suggests that mayoral governance is not a panacea for urban democracy. Perhaps it is too early to judge, but our 'before' (2012) and 'after' (2014) data suggests that trust in and timeliness of decisionmaking have improved only very slightly and are still low.

Some of the respondents to our research expressed the view that the way the mayoral model in Bristol is working is too centralised. The argument here is that, if too much power is concentrated in the hands of one individual, councillors and other stakeholders can come to feel excluded from the local policy-making process. This, in turn, may weaken the legitimacy of the decisions taken by the mayor and may diminish support for important initiatives. There is force in these criticisms.

\section{Wider implications for regional studies}

In an earlier article, we examined how the research on civic leadership in Bristol contributes to four questions that are well established in the international literature on urban or place-based lead- 


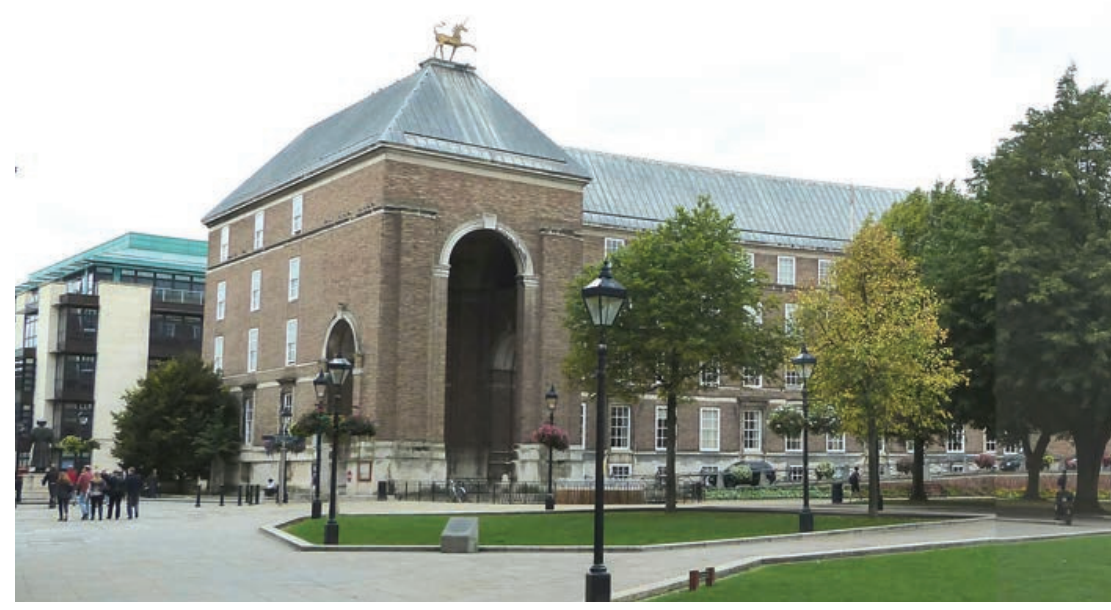

Bristol City Hall. (C) Paul Revell

ership (Hambleton and Sweeting, 2014). Here we provide a brief summary.

First, can the institutional design of local government make a difference to the way leadership is exercised? Our research confirms that institutional design can, indeed, make a difference in the Bristol case, a major difference. For example, it is clear that, by virtue of his direct election, Mayor Ferguson has been able to make radical decisions that would not otherwise have been possible. When asked about whether being directly elected made a difference to his approach to leadership he said: 'Being elected by the whole electorate creates a huge difference to my authority to do things. It also gives me the courage to make changes that, otherwise, would be very difficult to make' (Hambleton 2015, p. 135).

Second, does having a directly elected mayor promote an outgoing style of leadership? Again the evidence from the Bristol research is affirmative. It is clear that the mayoral model has provided a platform for highly visible, outgoing civic leadership. This development is noticeable both outside and inside the city.

The existence of the mayoral model of governance in Bristol has enabled Mayor Ferguson, and his team, to project a forward-looking and ambitious vision for the city to a variety of national and international audiences. While the groundwork enabling Bristol to win recognition as European Green Capital 2015 was carried out before Mayor Ferguson was elected, he added his own personal commitment to the initiative. These external-facing activities have helped to bring about a dramatic rise in the reputation of Bristol as an innovative, eco-friendly city.
The mayoral model also helps to lift the profile of the city leader within the city. For example, like directly elected regularly emphasises that he sees himself as leader of the place, not leader of the council. This is a subtle but important difference. On his first day in office he renamed the Council House, Bristol's civic headquarters, City Hall. Moreover, there is no doubt that he is a much more prominent public figure in Bristol city life than any previous leader. His personal style of leadership is, of course, an important factor here. For example, he is frequently seen walking or cycling about the city, makes extensive use of Twitter to communicate with the public and prioritises responding to media enquiries.

Third, does having a directly elected mayor change the relationships between politicians and officers? Again the evidence from Bristol suggests yes. The mayor has created a cabinet of senior politicians to provide him with advice. This contains a Deputy Mayor and three Assistant Mayors, and all the main political parties are represented. However, in the Bristol case the mayor has chosen not to delegate powers and responsibilities to senior councillors. Given that the mayor cannot possibly take all the decisions that have to be made in a major city like Bristol, it follows that the power and influence of senior officers within the city council has grown.

Fourth, does having a directly elected mayor change the relationships between city leaders and followers? The Bristol research suggests that the relationships of an indirectly elected leader, one who is a party leader and dependent on the support of councillors, are fundamentally mayors elsewhere, Mayor Ferguson different from those of a directly elected independent mayor. Mayor Ferguson claims that, because he is directly elected, he does not need to 'play the party game'. Instead, he puts energy into cultivating support in the community, in professional networks and in the business community. We should note, however, that directly elected mayors in other English cities who are party politicians - for example, the mayors in Leicester and Liverpool - work very closely with their party groups. To some extent, therefore, the changes we have recorded in Bristol reflect, not just the fact that a new leadership model of governance has been introduced, but also the fact that the present mayor is an Independent politician.

\section{References}

Fenwick, J. and Elcock, H. (2014) "Elected mayors: Leading locally?," Local Government Studies, Vol. 40, No. 4, pp. 581-99.

Hambleton, R. and Sweeting, D. (2014) "Innovation in urban political leadership. Reflections on the introduction of a directly-elected mayor in Bristol, UK," Public Money and Management, Vol. 34, No. 5, pp. 315-22.

Hambleton, R. (2015) Leading the Inclusive City. Place-based innovation for a bounded planet. Bristol: Policy Press.

Hambleton, R. and Sweeting, D. (2015) The Impacts of Mayoral Governance in Bristol, September, School for Policy Studies, University of Bristol. Available at: http://bristolcivicleadership.net

Robin Hambleton is Professor of City Leadership at the Centre for Sustainable Planning and Environments, University of the West of England, Bristol, UK and Director of Urban Answers, a company he founded in 2007. His main research interests are place-based leadership, public service innovation and international lesson drawing.

robin.hambleton@uwe.ac.uk

Dr. David Sweeting is a Senior Lecturer in Urban Studies at the University of Bristol, UK. His research and teaching interests focus on urban governance and politics generally, and urban political leadership particularly. $\mathrm{He}$ is currently editing a book on directly elected mayors, to be published in 2017.

david.sweeting@bristol.ac.uk 


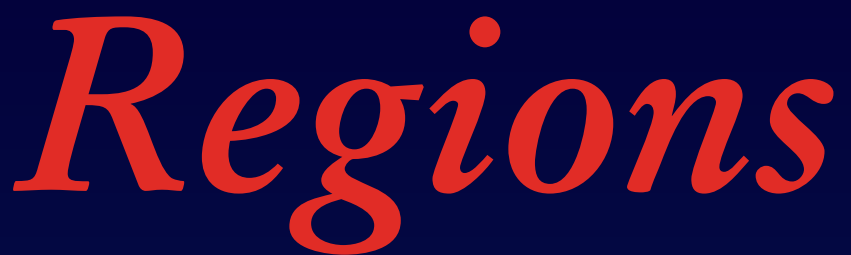

\section{The Voice of THe Membership}

In a packed issue, we harness the perceptions of academics from different parts of the UK on the nature of the debates in the regions on the question of the UK's membership of the EU.

The Regional Survey in this issue presents a selection of papers from a broader set of research papers presented and discussed at the RSA's International research network seminar on Leadership in Urban and Regional Development held in Birmingham, UK in November 2015 which addressed the theme of 'Exploring Varieties of Leadership in Urban and Regional Development'.

Our guest editors (Joyce Liddle, Aix-Marseille Université, John Gibney, University of Birmingham, Markku Sotarauta, University of Tampere, and Andrew Beer, University of South Australia) bring together a collection of interesting articles analyzing some of the main conceptual, theoretical, methodological and empirical debates surrounding Urban and Regional Leadership.

Leadership is a contested concept and much is written on the topic across a multitude of management and social science disciplines. There is, however, little agreement on what it is, or how to research it. Place leadership is one of the key factors explaining how some places are able to adapt to new situations, and to exploit emerging opportunities for transforming localities.

In the Survey there is an exploration of different conceptions and meanings of the term 'leadership' in urban and regional studies, an examination of the relative strengths and weaknesses of different methodological approaches to the study of urban and regional development leadership, and some case study examples of leadership in sub-national settings.

We also have case-study research from East Germany (growth paradigms); Italy (resilience of bergamot farmers) and S.E. Ireland (developing region-specific smart specialisations) in our In Depth and Research Notes sections, respectively.

This is all rounded off with a report on the Annual Conference in Graz, Austria.

\begin{tabular}{|c|}
\hline Regional \\
\hline Studies \\
\hline Association \\
\hline THE GLOBAL FORUM FOR CITY \\
AND REGIONAL RESEARCH, \\
DEVELOPMENT AND POLICY
\end{tabular}

Regional Studies Association, PO Box 2058, Seaford, East Sussex BN25 4QU, UK Tel: +44 (0)I323 899 698, Fax: +44 (0)I323 899798 info@regionalstudies.org, www.regionalstudies.org

Registered Charity No: 1084165

Registered Company, Limited By Guarantee In England No: 4116288

Typesetting and Printing by Sussex Living Ltd 